\title{
A note to transfer pricing audit performance by Indonesia's tax administration based on tax court decision 2015-2019 on manufacturing industry
}

\author{
Maria R.U.D. Tambunan \\ Department of Fiscal Administrative Science, Universitas Indonesia, Jakarta, Indonesia \\ Corresponding author email: maria.tambunan@ui.ac.id
}

\section{A R T I C L E I N F O}

Article history:

Available online

\section{Keywords:}

Transfer pricing, tax audit, arm's length principle, international taxation

DOI: https://doi.org/10.20885/jaai.vol24.is s2.art2

\section{A B S T R A C T}

This research discusses the transfer pricing audit performance of Directorate General of Taxes (DGT) based on the tax court stipulation during fiscal year 2015-2019. This research employed qualitative research method. The data were collected through literature review and interview. The findings showed that the cases brought to the tax court solely due to administrative and technical matters had been quite significant in number, which were more than $40 \%$ of the cases settled. Unfortunately, inappropriate assessment process took the larger proportion in the failure in complying with the technical and administrative rules while conducting the audits. On the other hand, in regards with non-technical and administrative issues, DGT mostly won the cases. It means that DGT were more reliable in auditing once it complied with the technical and administrative matters. The research also showed that DGT fully realized that the infrastructure of transfer pricing handling needed supports from various aspects.

\section{Introduction}

Transfer pricing has been considered as the most common modus of tax avoidance performed by MNEs (Chan et al., 2015) and similarly has been considered as a rigorous audit on tax compliance (OECD, 2010). With these transfer pricing characteristics, as part of taxation obligation which must be performed by multi corporate group, transfer pricing has been an important concern, arising even in the major discussions in the academic and political debate on the future domestic tax law and international taxation forum (Schön \& Konrad, 2012). From the financial issue perspectives, as highlighted in UN Practical Manual on Transfer Pricing for Developing Countries (2017), "transfer pricing is probably the most important cross-border tax issue globally. This is partly because the term multinational enterprise (MNE) does not only cover large corporate group but also smaller group with one or more subsidiaries or permanent establishments (PEs) in countries other than those where the parent company or head office is located".

Transfer pricing is, a fact-intensive assessment work but it does not offer a constant formulaic basis like other exact sciences. Most of the countries throughout the world have adopted the rules proposed by OECD through OECD Transfer Pricing Guidelines for MNEs in their domestic transfer pricing rules. It means that they have implemented the arm's length principle method to calculate the related party's transaction as proposed in OECD Transfer Pricing Guidelines (McNair et al., 2010; Vega, 2012). However, in fact, the utmost challenges faced by the tax administrators in developing countries in transfer pricing matters are not solely due to the non-existence of the standardized formula to assess the fairness of transfer pricing transactions using the available comparable data relevant to their market, but importantly also due to lack of capacity, including the available system or mechanism to monitor the MNEs transactions with their partners (McNair et al., 2010). The relatively similar problems were also confirmed by OECD observers while conducting surveys on transfer pricing implementation in developing countries.

Beside the challenges on human capital capacity and the availability of the mechanism, the United Nations Committee also pointed out that the existence of comparable data to be used as tools for auditing remained insufficient. Several developing countries considered the data generated from developed countries as comparable. Indeed, it could not be a solution because the market conditions including the location or geographical locations that affect the market performance would be quite different compared to the market in developing countries, where the tools of comparable were used (United Nations, 2009).

Furthermore, related to the challenges, based on the surveys performed by OECD in 2012 to 43 member countries of Forum Tax Administration (FTA) which consists of OECD and non-OECD members, the following are the practical challenges needed to overcome: (i) The most common risks of tax audit are transfer pricing cases. (ii) 
Transfer pricing audit is fact-intensive and more complicated compared to other tax audits. Thus, the release of the report will take longer time. Most of FTA member released the transfer pricing audit report within 12 months or even up to 540 days. (iii) In some jurisdictions, the revenue collected from transfer pricing audit was not quite large. There was even a question whether the costs of audit were covered by the revenue collected by the audit. (iv) The information gathered from other countries would be really help to ease the audit process. (v) The number of cases settled for each year is not as high as other cases. (vii) The availability of risk assessment is quite important before undertaking the audit. It will efficiently save resources to be allocated into the priority.

During the SGATAR (Study Group on Asian Tax Administration and Research) meeting in 2019, the group members also highlighted that the transfer pricing issues were still the challenges faced by most of the countries. The transfer pricing challenges discussed in the forum included availability of comparable data, transfer pricing dispute settlement, information exchange to ease the audit, and optimization of technology for the audit (kontan.co.id, 2019). At the end of 2019, KPMG raised the other issues related to transfer pricing dispute, that was the lack of uniform approach undertaken by the tax court during the judgments of transfer pricing adjustment. The lack of uniform approach was driven by many aspects including the administrative matters. It indicates the higher degree of uncertainty which must be faced by the taxpayer and tax authority (KPMG, 2019).

How to deal with transfer pricing issue is also one of DGT agenda to undertake an institutional reform (CNBC Indonesia, 2018; Inside Tax, 2013). In fact, DGT also recognized that it was really challenging to minimize the transfer pricing disputes (Bisnis.com, 2015). Currently, several continuous measures have been performed to improve the organization capacity to keep up with the global transfer pricing issue. The establishment of Transfer Pricing Management Centre under Jakarta Regional Office is also an institutional effort to improve the tax auditor capacity. It is also expected that this center of excellent will facilitate the tax auditors to keep updated with the global transfer pricing issues worldwide and ensure that each audit report made will follow the prevailing rules (Ditjen Pajak, 2019a).

Moreover, in 2019, Indonesian tax authority, Directorate General of Taxes (DGT) organized a National Transfer Pricing Forum to discuss the transfer pricing issues that became more crucial and practiced myriad times by MNEs (Ditjen Pajak, 2019b). On the other hand, the myriad of cases brought and settled in Indonesia Tax Court during the fiscal year 2014-2019 showed that this issue would be a continuous work to deal with in this globalization era. Furthermore, based on the empirical research assessed on the tax court decision during the fiscal year 2014-2019, it can be seen that the DGT failures to win the cases in the tax court were mostly due to the disputes over the non-transaction related issues. This article is to discuss the Indonesian tax authority transfer pricing audit performance and how they deal with transfer pricing cases. This article is also aimed to provide inputs to Indonesian tax authority.

\section{Literature Review}

\section{Fundamental Aspects of Transfer Pricing Audit}

The complexity of transfer pricing assessment might be affected by the fact that giant MNEs commonly established the intermediaries, holding and sub-holding entities scattered in different jurisdictions. With this structure, the management of an MNE might make the decisions following its business model whether it is centralized or decentralized. Following the chosen business model, the management probably has established the following structures (United Nations, 2017):

a. R\&D activities and services which probably are concentrated in a center located in a particular jurisdiction that has been engaged to support the whole group or a certain unit of group;

b. The intangibles which may be developed by a particular other group engaged for the advancement of business of the whole members of an MNE group;

c. A particular part of group which has been engaged as the finance and "captive insurance companies" which may operate as insurer or internal finance company;

d. Production units, which have been functioned as production and assembly units for the fabrication of final products. These activities may also have been assigned to the units in many jurisdictions around the world.

With this complexity, therefore, as a general transfer pricing exercise, various steps need to be involved, such as gathering the background information about the business, performing industrial analysis, performing comparability analysis including functional analysis, selecting the methods to determine the arm's length price, and determining the arm's length price (United Nations, 2017). In short, it could be said that the effective risk identification and assessment process are the important steps to ensure the most appropriate cases to be selected for audit. Since the transfer pricing is a cumbersome process, which acquires more energy and time, with the existing constraints, making the categories of risks before performing the audit should be a considerable step. UN Practical Manual on Transfer Pricing (2017) categorizes the complexity of risks into four categories in a nonexhaustive list as the following: 
1. Category 1: intentional profit shifting through new structure that is possibly performed by MNEs through the mode of saving arrangements;

2. Category 2: intentional profit shifting through restructuring which is possibly made in various jurisdiction. The detection to restructuring driven by profit shifting may not be easily detected, however, it can be identified through static profit margins or through the change in VAT returns;

3. Category 3: intentional profit shifting through incorrect functional classification, the use of incorrect methods, and allocation keys;

4. Category 4: thin capitalization.

Transfer pricing assessment made by tax auditor begins with the examination of the documents submitted by a taxpayer. In every stage of the transfer pricing assessment process, varying degrees of documentation is necessary, such as information on contemporaneous transactions. On the taxpayer's side, one pressing concern regarding transfer pricing documentation is the risk of disproportionately high cost in obtaining relevant documentation or high cost of exhaustive search for comparable that may not exist. Even though transfer pricing is fact-exhaustive, as highlighted by UN Practical Manual on Transfer Pricing, ideally, the taxpayer should not be pressed to provide more documentation than is objectively required for a reasonable determination by the tax authorities of whether or not the taxpayer has complied with the arm's length principle. Beside for the purpose of determination of fair price and tax compliance obligation, the cumbersome documentation demands may affect how a country is viewed as an investment destination and may also have particularly discouraging effects on business especially new cross-border small and medium-sized enterprises (SMES) (United Nations, 2017).

The dispute may occur even though the transfer pricing rule has applied and has been followed by both tax administration and taxpayer. This occurrence raised when the tax administration and taxpayers reached a different determination to the arm's length condition, or both parties reached a different view on the transaction that was considered as fair price. The complexity of certain transfer pricing cases and the difficulty to interpret those cases lead the taxpayer and tax administration to different positions (OECD, 2017).

When a member of MNEs is under transfer pricing audit, it may affect the other members located in different jurisdictions due to the cross-border transaction undertaken. However, each country has certain procedures that may make the audit process different in each jurisdiction. At the same time, the assessment of transactions using arm's length principle as a tool for audit to realize a vertical and horizontal fairness has been a common rule. Transfer pricing examination presents special challenges compared to normal tax audit practices. OECD (2017) mentioned that "transfer pricing cases are fact-intensive and may involve difficult evaluation of comparability, markets, and financial or other industry information. Consequently, a number of tax administrations must have examiners who specialize in transfer pricing and transfer pricing examinations which may take longer than other examinations and follow separate procedure".

Furthermore, OECD (2017) also mentioned that certain difficult transfer pricing cases, due to its complexity and fact intensity which must be evaluated, might enable "even the best-intentioned taxpayer make an honest mistake, moreover even the best-intentioned tax examiner may draw a wrong conclusion from the facts". Viewing this propensity, it is suggested that tax auditors be more flexible with the methods they use for audit depending on the factual conditions of the transactions and economic conditions when the transaction was undertaken. The existence of burden of proof will be very crucial during making a judgment to a transaction. As noted by OECD (2017), "in some countries, the burden of proof can be reserved, allowing the tax administration to estimate taxable income, if the taxpayer is found not to have acted in good faith, for example, by not cooperating or complying with reasonable documentation requests or by filing false or misleading tax returns".

\section{Research Method}

Basically, taxation is an inter-disciplinary and multidisciplinary research (Lamb et al., 2004). The paradigm of this research is constructivist/interpretive. Ontologically, this paradigm has basic premises of questioning the reality that need to constructed. In this paradigm, reality is limited to context, space, group, time, individual, group in a particular situation. In this research, the phenomenon of transfer pricing audit performance in manufacturing industry to ascertain their compliance with the transfer pricing rules will be thoroughly scrutinized then interpreted.

This research used qualitative method. The qualitative research concerns on why and how a phenomenon could occur in the society. The method intends to understand and interpret the social issues and cases. Therefore, qualitative research must not be performed in a conventional laboratory. To conduct a qualitative study, a researcher would file the research after series of literature review. However, the literature review in this method does not intend to prove the theory, rather, the theories function as a framework for the researcher's critical thinking. Qualitative research method is not value-free which means that the researcher may be influenced by the value thriving the in society. 
In qualitative research, the researcher does not aim to prove the theory like the quantitative researcher does. Quoting Creswell (2014) related to qualitative research, "in a qualitative study, one does not begin with a theory or test or verification. Instead, consistent with the inductive model of thinking, a theory may emerge during the data collection and analysis of the research, or be used relatively late in the research process as a basis for comparison with other theories."

This study is a descriptive research that is intended to describe the phenomenon in detail. Thus, this study described how Indonesian tax authority had performed transfer pricing audit as fact-intensive audit by following the current transfer pricing provisions in Indonesia. This research also described the details of challenges faced by the transfer pricing auditors while conducting their work. The initiative to assess how transfer pricing audit has been done is induced by the myriad number of transfer pricing cases which were brought to the tax court. The data were collected through literature review, documentation study, interviews with the informant and the third party, and assessment results on tax court decisions related to transfer pricing during the fiscal year 2015-2019. The process of data collection was conducted in the following steps:

1. The researcher accessed the database of tax court and separated the transfer pricing cases and non-transfer pricing cases stipulated during the fiscal year 2015-2019.

2. After identifying the transfer pricing cases, the researcher analyzed the main drives of the case, the tax audit performance, the tax authority standpoint, the taxpayer standpoint, and what and how the judges stipulated the cases.

3. The researcher classified the cases into those won by the taxpayers and those won by the tax authority

4. The researcher classified the reasons why the taxpayer won or lost and why the tax authority won or lost.

5. The researcher applied OECD Manual Transfer Pricing Guidelines as the framework of thinking. The researcher also made a reflection on what OECD Manual Transfer Pricing Guidelines propose, how Indonesian domestic provisions govern, and how the cases were assessed during the litigation.

6. From the classification, the researcher was able to abstract the findings.

After gathering the data and generating findings, the researcher conducted the interviews with the stakeholders (DGT, academics, tax consultants, and taxpayers) to get their perspectives on the findings. For the analysis, this research employed an inductive analysis which was started with the discussion from general topics to specific ones. The researcher started from the general transfer pricing cases and inductively moved to the issues on transfer pricing audit performance vis a vis transfer pricing process that induced many cases which were brought to and settled in the tax courts.

\section{Results and Discussion}

\section{Transfer Pricing Audit Performance Based on Tax Court Decision in Indonesia}

Transfer pricing audit has become the common taxation audit in Indonesia since the tax administration found that hundreds of MNEs did not pay taxes due to the continuous loss while they kept on operating in Indonesia. That fact significantly contributed to the change of Indonesia tax regulations, specifically transfer pricing rules (Tambunan et al., 2020). The guidelines for transfer pricing documentation obligation was enacted in 2010 by the release of PER-43/2010 on the implementation of arm's length price principle. Later, the technical guidance to conduct transfer pricing audit must be based on the Directorate General of Taxes Circular Letter No. SE-50/PJ/2013 (SE-50). The issuance of this Circular Letter was to provide a standardized transfer pricing audit process (PWC, 2013). Transfer pricing audit is the activities related to the identification of the risks of the affiliated transactions performed by the affiliated taxpayers. The following are the indicators to identify to what extent the risk might be undertaken:

a. The significance of the affiliated transaction indicated by the proportion of sales or net profit as the basis of risk valuation.

b. The transaction specifically made with the related party, including the payment for transfer of intangibles, payment of royalties, payment for the performance of intra-group services and payment of interest.

c. The significantly low difference in the taxpayer's net profit compared to the other business entities within the similar industry.

d. The significance of or the extent to which the transaction with the affiliation generated net profit for the audited taxpayer. The rationalization of the components of net profit earned from the affiliation economic activities is needed.

e. The amount of interests paid to the affiliation and/or non-affiliation.

f. Gain or loss on the sales of an asset.

g. Gain or loss from foreign exchange.

h. Non-routine affiliated transactions. Non-routine transactions with the affiliation may include business restructuring that involves or does not involve intangible assets as well as the sales of intangible property; and 
i. The taxpayer has suffered from losses for several years.

Long time before the release of the regulation, Directorate General of Taxes (DGT) released the Circular Letter No. SE-04/PJ.7/1993 which mentioned that the mispricing might be performed through one or more following transactions (a) selling price, (b) purchasing price, (c) overhead cost, (d) shareholder loan, (e) payment on commission, license, franchise, rent, royalty, management fees, technical fees and other payment on services to affiliation, (f) acquisition of assets or shares made by shareholder in which the price is below the market price, (g) selling of goods/services to the entities in other jurisdiction with lack of economic substance such as payment to dummy company, letter box company, or rein voicing center.

On 13 August 2018, DGT issued the revised technical guidance for transfer audit, i.e. Circular Letter No. SE-15/PJ/2018 (SE-15) concerning tax audit policy. Pursuant to SE-15, various indicators are used to determine whether or not a taxpayer must be included in transfer pricing audit priority target list with regard to transfer pricing issues. Below are the indicators used.

a. The taxpayer has the transactions with the affiliates that are subject to a zero or lower effective tax rate;

b. The indications that a taxpayer is involved in a transaction scheme involving entities that do not have business substance or do not add economic value (rein voicing);

c. The taxpayer has significant affiliate transactions, particularly in relation to the value of sales;

d. The existence of intra-group transactions, such as the provision of services, payment of royalties, and cost distribution arrangements;

e. The existence of business restructuring transactions, such as mergers and acquisitions;

f. The taxpayer's financial performance differs from the financial performance of the industry; and

g. The taxpayer has had consecutive losses for three tax years out of the previous five years.

Generally, the tax audit process as governed in SE-50 jo. PER-22/PJ/2013 involves three stages (PWC, 2013):

1. Preparation stage, where the tax auditor will sort the identified risk taxpayers by assessing their income tax returns. The initial review will be made to the financial statement. Then, the further assessment will be done related to the significance of the related party transactions to the whole business process, the volume of transactions made to the entities related in lower tax jurisdiction, the value of the transactions related to the intangibles, intra-group services and interest expenses. Furthermore, there will be an assessment on the rate of profitability of the audited taxpayer compared to that of the other entities in similar business, non-routine transactions to related party, and the possibility of perpetual loses.

2. Implementation stage, where the tax auditor will issue the tax audit notification informing that the tax audit process has officially commenced. The tax auditor may ask for more comprehensive data other than those already submitted. The tax auditor will also ask for the explanation prior to the transaction or may use the exchange of information (EOI) to get the comprehensive information or to verify the reported transaction. It is also possible that the taxpayers ask for the information from related domestic entities with whom the audited entities made transaction. During this stage, the tax auditor performs the function, asset, and risk (FAR) analysis deeply. The FAR analysis is not only based on the information disclosed by the taxpayer, but also that disclosed by the taxpayer's related partners.

3. Reporting stage, where the tax auditor discloses their working paper and the findings based on the regulation. The tax auditor must also present their findings and their position to conclude the transfer pricing audit.

The current provisions of TP Audit implementation in Indonesia referring to PER-22 governs the following things:

a. Determination of the audit scope and step-by-step. It may consist of the assessment on the characteristics of business and determination of business model. In this stage the auditors also assess the characteristics of the related party transaction, the terms \& conditions of the transaction, the characteristics of group business, and the financial conditions of the group business.

b. Determination of transfer pricing methods. The tax auditor may determine the most appropriate method within the acceptable methods (comparable uncontrolled price, resale price, cost plus, profit split, transaction net margin method, or other method) after considering the pros and cons of each method, the fitness of the method with the assessed transaction, the availability of information, and the comparability of the selected method with audited transaction.

c. Comparability analysis. The auditor selects the availability of the comparable data in relation to the selected transfer pricing method based on the fact and circumstances. In this stage, the tax auditor may make adjustments to the comparable data as the tools for audit or use multiple-year data solely to reach the higher degree of comparability.

d. The step-by-step to perform transfer pricing audit to ascertain each transfer pricing audit activities has passed the standard. 
e. The principle of transfer pricing audit for each audited transaction. For example, for intra-group services, the auditor may assess the economic benefits and the existence of the services.

f. The report of audit finding

g. The assessment on the submitted documentation

Having implemented the technical guidelines as widely published by DGT, the auditor determines the strategics of audit based on the business model of the taxpayer and the characteristics of the business. The business model refers to the production activities whether it is decentralized or non-decentralized model, and the characteristics of the business refers to the functions of the entities whether they act as fully-fledged manufacturer, contract manufacturer, or toll manufacturer. After determining the model and characteristics of the business, the formal technical guidelines apply during the transfer pricing audit process. As stated in DGT Circular Letter No. S153/PJ.4/2010, the determination of business model and characteristics must not be based on legal and documentation approach, but it must be based on the substance of the economic activities (substance over form test). Then, the function, asset, and risk (FAR) analysis must be made prior to the transfer pricing audit. This analysis is the initial step by step forward to the selection of transfer pricing method assessment (Silaban, 2015). The following is the comparison between the decentralized business model and centralized business model that is commonly used as a tool for business model identification.

Having determined the business model of the taxpayer subjected to transfer pricing audit, the tax auditor categorizes the characteristics of business based on the following distinction tool.

Table 1. The Categories of Business Functions

\begin{tabular}{|c|c|c|c|}
\hline $\begin{array}{c}\text { The Characteristics of Business } \\
\text { Functions }\end{array}$ & $\begin{array}{l}\text { Fully-Fledged } \\
\text { Manufacturer }\end{array}$ & Contract Manufacturer & Toll Manufacturer \\
\hline Overall business function & $\begin{array}{l}\text { Performing all of } \\
\text { functions starting from } \\
\text { R\&D until the selling of } \\
\text { products }\end{array}$ & $\begin{array}{l}\text { Limited to the } \\
\text { procurement of raw } \\
\text { materials and processing } \\
\text { the products until the } \\
\text { finished goods }\end{array}$ & $\begin{array}{l}\text { Limited to production } \\
\text { process }\end{array}$ \\
\hline Decision making function & All of business activities & $\begin{array}{l}\text { Limited to certain } \\
\text { activities }\end{array}$ & $\begin{array}{l}\text { No authority to make } \\
\text { decision }\end{array}$ \\
\hline Ability to fabricate the products & Performed & Performed & Performed \\
\hline Management of supply chain & Performed & Performed & Performed \\
\hline $\begin{array}{l}\text { The ownership of procured raw } \\
\text { materials and supplies }\end{array}$ & Authorized & Authorized & Not authorized \\
\hline $\begin{array}{l}\text { Obligation to bear the risk of } \\
\text { procurement }\end{array}$ & Yes & Minimum risk & No \\
\hline Obligation to bear the credit risk & Yes & Minimum risk & No \\
\hline Obligation to bear the market risk & Yes & Minimum risk & No \\
\hline
\end{tabular}

Sources: Circular Letter of DGT No. S-153/2010

Thus, the technical practice of transfer pricing audit (implementation stage) will undergo the following sequences: (1) determining the characteristics of business and business model, (2) selecting the transfer pricing method, and (3) determining the arm's length assessment to ensure that the fair price transaction has been applied.

Assessing the current transfer pricing practical guidelines to perform the audit then reflecting current Indonesian regulations to the UN highlight on documentation must be provided by the taxpayer. The current implemented regulations apparently fulfill the minimum lists of documents required for the audit as classified by the UN as listed below (United Nations, 2017).

a. Enterprise-related documents, such as the ownership or shareholding pattern of the taxpayers, the profile of business and the group, the profile of industrial whereby the business undertaking the activities;

b. Transaction-specific documents, such as the details of each international transaction, functional analysis on the taxpayer and associated enterprises, record of uncontrolled transaction for each international transaction;

c. Computation-related documents that provide the information related to the nature of each international transaction and the rationale behind the decision to select a particular transfer pricing method for each crossborder transaction, the computation of the arm's length price, the factors and assumptions influencing the determination of the arm's length price. 
Table 2. Summary of Tax Court Decisions Won by Taxpayer and Tax Administration

\begin{tabular}{|c|c|c|c|c|}
\hline No & Cases Won by Tax Auditor & $\begin{array}{c}\text { Fiscal Year } \\
\text { Stipulated }\end{array}$ & Cases Won by Taxpayer & $\begin{array}{l}\text { Fiscal Year } \\
\text { Stipulated }\end{array}$ \\
\hline \multicolumn{5}{|c|}{ Payment on Intangible Property (Royalty Payment) } \\
\hline 1 & Put-089897.15/2011/PP/M.IIA/2018 & 2018 & Put-086980.15/2011/PP/M.XVIA/2018 & 2018 \\
\hline 2 & Put. 82925/PP/M.XVIIIB/15/2017 & 2017 & Put- 81509/PP/M.XVIIIA/15/2017 & 2017 \\
\hline 3 & Put-80603/PP/M.IIIB/15/2017 & 2017 & Put. 68310/PP/M.IVB/15/2016 & 2016 \\
\hline 4 & Put.84903/PP/M.XIA/15/2017 & 2017 & Put.59386/PP/M.XIA/15/2015 & 2015 \\
\hline 5 & Put.84904/PP/M.XIA/15/2017 & 2017 & Put.70118/PP/M. IA/15/2016 & 2016 \\
\hline 6 & Put-80603/PP/M.IIIB/15/2017 & 2017 & Put. 62911/PP/M.XVB/15/2015 & 2015 \\
\hline 7 & Put.79846/PP/M.XII/A/15/2017 & 2017 & Put. 62911/PP/M.XVB/15/2015 & 2015 \\
\hline 8 & Put. 79851/PP/M.XIIA/15/2017 & 2017 & & \\
\hline 9 & Put.73689/PP/M.XA/15/2016 & 2016 & & \\
\hline 10 & Put.60993/PP/M.IVA/15/2015 & 2015 & & \\
\hline \multicolumn{5}{|c|}{ Payment of Interest on Loan Characterized as Capital } \\
\hline 11 & Put-063157.15/2008/PP/M.XVIB/ 2018 & 2018 & & \\
\hline 12 & Put-091982.15/2008/PP/M.VIIIB/2018 & 2018 & & \\
\hline 13 & Put-79851/PP/M.XIIA/15/2017 & 2017 & & \\
\hline 14 & Put-80671/PP/M.XVIIIB/15/2017 & 2017 & & \\
\hline \multicolumn{5}{|c|}{ Payment on Intragroup Services } \\
\hline 15 & Put- 109167.15/2013/PP/M.XVIIIB/2018 & 2018 & Put.73689/PP/M.XA/15/2016 & 2016 \\
\hline 16 & Put-092163.13/2006/PP/M.IIA/2018 & 2018 & & \\
\hline 17 & Put- 81638/PP/M. XA/15/2017 & 2017 & & \\
\hline 18 & Put-79851/PP/M.XIIA/15/2017 & 2017 & & \\
\hline 19 & Put-68310/PP/M.IVB/15/2016 & & & \\
\hline \multicolumn{5}{|c|}{ Payment on Intracompany Sales } \\
\hline 20 & Put-82597/PP/M.XIIA/15/2017 & 2017 & Put-87397/PP/M.VIB/15/2017 & 2017 \\
\hline 21 & Put-68106/PP/M.XIIB/15/2016 & & Put.62007/PP/M.IA/15/2015 & 2015 \\
\hline \multicolumn{5}{|c|}{ Payment on Intracompany Purchase } \\
\hline 22 & Put. 82405/PP/M.XIVB/15/2017 & 2017 & & \\
\hline 23 & Put- 73688/PP/M.XVIIIA/15/2016 & 2016 & & \\
\hline \multicolumn{5}{|c|}{ Cases due to technical and administrative aspects } \\
\hline \multicolumn{5}{|c|}{ Cases due to technical and administrative aspects } \\
\hline 24 & Put-59284/PP/M.VIA/15/2015 & 2015 & Put-107348.15/2013/M.XIV.B/2018 & 2018 \\
\hline 25 & Put-61248/PP/M.XVA/15/2015 & 2015 & Put-107945.15/2013/PP/M.IIIA/2018 & 2018 \\
\hline \multicolumn{5}{|c|}{ Difference of Method on Assessing Arm's Length } \\
\hline 26 & & & Put.68417/PP/M.III/15/2016 & 2016 \\
\hline 27 & & & Put.69375/PP/M.XIIB/15/2016 & 2016 \\
\hline 28 & & & Put.68375/PP/M.XIIB/15/2016 & 2016 \\
\hline 29 & & & Put.69440/PP/M.IIIA/15/2016 & 2016 \\
\hline \multicolumn{5}{|c|}{ Cases due to Inapproppriate of Assessment Process } \\
\hline 30 & & & Put-81622/PP/X.XIVA/15/2017 & 2017 \\
\hline 31 & & & Put.84911/PP/M.XIIIA/16/2017 & 2017 \\
\hline 32 & & & Put.84911/PP/M.XIIIA/16/2017 & 2017 \\
\hline 33 & & & Put.84913/PP/M.XIIIA/16/2017 & 2017 \\
\hline 34 & & & Put.84914/PP/M.XIIIA/16/2017 & 2017 \\
\hline 35 & & & Put. 84915/PP/ M. XIIIA/ 16/2017 & 2017 \\
\hline 36 & & & Put. 84916/PP/M.XIIIA/16/2017 & 2017 \\
\hline 37 & & & Put. 84917/PP/M.XIIIA/16/2017 & 2017 \\
\hline 38 & & & Put. 84918/ PP/ M. XIIIA/16/2017 & 2017 \\
\hline 39 & & & Put. 84919/PP/M.XIIIA/16/2017 & 2017 \\
\hline
\end{tabular}

Source: Indonesia Tax Court Secretariat, 2019

By applying the technical audit standard, the tax auditor does a further assessment on how the transfer pricing audit has been conducted and how the outstanding cases are settled. During the fiscal year 2009-2013, the board of judges rejected more than $45 \%$ of the transfer pricing audit performed by the tax authority. The reasons for the rejection were lack of convincing readjustment made by the tax auditor on the transfer pricing documentation submitted by the taxpayer, lack of supporting documents prior to the transaction reported, lack of sufficient argument or proof to the correction made by the tax auditor. The nature of assessment which was based on the assumption made the process become more complicated (The Jakarta Post, 2014). The motive of this "style of audit" in particular cases was driven by the pressure to optimize the revenue since DGT targeted to collect revenues annually until reaching a particular amount (Simamora \& Hermawan, 2017). 
The relatively similar findings were also collected within the fiscal year 2013-2016 by the researcher based on the empirical research. The study concludes that the correction made by DGT for specifically intra-group service transactions were mostly lack of supporting evidence. Besides, more than half of appeals proposed by the taxpayers were in favor of the taxpayers, solely due to lack of evidence submitted by the tax auditors to show how the taxpayers made corrections and readjustments. Unfortunately, in fact, until recently no detailed rule regulates to what extent each party must present the documentation (Simamora \& Hermawan, 2017). Moreover, based on the empirical research undertaken solely for the purpose of this study, there is a necessity to scrutinize the transfer pricing cases in favor of each party, taxpayer and tax administrator. The summary of cases settled in tax court published publicly by Tax Court Secretariat starting from the fiscal year 2015 until July 2019 is presented in Table 2.

The latest findings as presented in Table 1 also confirm that the cases brought to the tax court which were mostly due to the administrative and technical matters during the tax audit were quite significant in number. Even for some audits, the tax authority made the documentation as a sole consideration to conclude the audit findings. However, lack of the document requested by the tax auditor does not automatically mean that the taxpayer has abused the transfer pricing rules, performed profit shifting, been considered as non-compliant (from the interviews with tax practitioners). For the technical things induced tax litigation, more than $40 \%$ of the cases were settled during the fiscal year 2015-2019. Surprisingly, inappropriate assessment process took the larger proportion of the failures in complying with the technical and administrative rules. On other hand, for non-technical and administrative issues, DGT tended to win the cases. It means that DGT were more reliable in doing the audit complied with the technical and administrative matters. DGT has also experienced the increasing propensity of winning the cases starting from the fiscal year 2017. It also indirectly indicates that the transfer pricing skills gained by DGT has increased over the years and the way of the tax auditor performing the audit has been more thorough in manner.

Regardless the enhancement in transfer pricing audits undertaken by tax auditors, several challenges still need to deal with. Formerly, based on the empirical research of Silaban (2015) and confirmed through the interviews with the stakeholders, the technical challenges of transfer pricing audit in Indonesia are caused by several factors:

a. Different understanding of selected comparable data from external database. Beside the different understanding of both parties, the time is also limited to have intensive discussion on the selection of comparable data; why and to what extent each party has the underlying basis to select the comparable data as the tool of comparability. Moreover, the internal commercial database could not be utilized as the solid comparable data because those data are established not solely for the purpose of transfer pricing but for more general financial purposes. This situation is worsened by the mutation of the tax auditor from a particular tax office to another tax office in different location that makes the responsible tax auditor must be shifted to the new appointed auditor before the transfer audit is settled.

b. The tax auditors are overload with the audits, and each auditor must report the "findings" at the certain time. In this situation, the tax audit does not seem to assess the compliance of the taxpayer, but it is to find the taxpayer's faults or just to reach the tax revenue target. Therefore, the audit report was occasionally made carelessly. On the other hand, each tax auditor also has different level of knowledge, experiences, and expertise in transfer pricing. These lead to lack of quality on audit result. To deal with these challenges, continuous training and learning, knowledge sharing, and updating the international transfer pricing trend issues are really needed (Prasetyo, 2016). How the transfer pricing audit responsibility should be distributed to each auditor needs to be reviewed by the respective unit.

c. DGT has established the audit quality assurance unit, however, the effectiveness and neutrality of the performance of this unit remain to be questioned by the taxpayers since this unit is an internal part of DGT. It seems clumsy if the taxpayers propose the findings of transfer pricing audit or the process of transfer pricing audit to be reassessed by this unit (from the interviews with the taxpayers and tax practitioners).

d. In fact, the transfer pricing is not an exact science. This transfer pricing nature as that of non-exact sciences indirectly affects how each party behaves on a transfer pricing treatment for particular transaction. Each party picks a comparable data with its own arguments and justification for the behavior.

e. No certain technical guidelines for the selection of comparable data seems a source of continuous dispute.

This fact justifies the UN highlight on the ability of developing countries to handle transfer pricing issue. As it mentions that the country with less sophisticated taxation system and administration capacity would have run the risk on absorbing the effects of stronger enforcement of transfer pricing (United Nations, 2017). Furthermore, the UN also identifies the common challenges faced by the developing countries, which are also faced by Indonesia. Those typical challenges include (United Nations, 2017):

a. Lack of comparable. The comparable data available in developing countries tend to be incomplete, and probably the appropriate comparable data from the independent entities do not simply exist. The reliable 
comparable data to inform the business in developed country would not be quite relevant for developing country. With this fact, making a reliable transfer pricing analysis in developing country for both tax administration and taxpayers might still be problematic.

b. Lack of knowledge and requisite skill sets. Transfer pricing methods are fact-intensive, time-consuming, and requiring serious attention to handle. With limited resources and information, the need to enhance the skills, knowledge, and expertise in transfer pricing issue is inevitable.

c. Complexity. Along with the time, the transfer pricing rules will become more complex due to the complexity of transactions. This leads to more complex responsibility to administer the tax obligation. How the legislation and regulation-making system should accommodate this inherent complexity is also the following homework.

d. The availability of infrastructure such as information technology system that enables the tax authority to get support in implementing the effective strategy to encourage transfer pricing compliance and easing the administration settlement and litigation process.

In 2010, several years after the transfer pricing cases raised the attention of DGT, DGT initiated to establish a specific team to deal with transfer pricing issues and specifically to handle Mutual Agreement Procedure (MAP) as mandated by DGT Regulation No. PER-48/PJ/2010 which has been effective since November 3, 2010. This team is responsible to ascertain the DGT position on particular transfer pricing case. As part of the responsibility, the team has been engaged to coordinate and supervise the units under DGT which monitor MNEs business performance in the related transactions (Ortax.Org, 2010). The composition of the team members consists of the people from several units of DGT to pool the team expertise, considering that transfer pricing issues must be analyzed by the experts from various backgrounds (Ortax.org, 2010). In 2017, DGT also established a specific section and unit to perform tax audit on certain transactions, in which the transactions with affiliations become the important focus. In short, the transfer pricing issues have changed the organization structure of DGT and the way they do their business.

With regard to the transformations made by DGT, the following tax administration functions are commonly established in most countries for the purpose of transfer pricing matters, including (a) audit section that specifically engages with transfer pricing risk assessment and transfer pricing audit, (b) specialist advisory function that engages with the formulation of the provisions of technical guidances on audit, dispute resolution, settlements, and negotiation of APAs, (c) the specialist that has competence in mutual agreement procedure and APA (United Nations, 2017). The organizational structure established by DGT has followed the UN suggestion. Whether the newest structure has been optimized to perform the responsibility and has made optimal coordination are the new challenges.

Prior to the increasing propensity of the cases in favor of DGT, DGT already made the measures to improve its human resources capacity and knowledge, such as by administering regular in-house training (from the interviews with DGT transfer pricing trainer, 2020). In 2019, DGT organized a national forum on transfer pricing issues that brought the stakeholders (such as tax consultants, independent auditors, academics, business, etc.) together into one forum to identify the common challenges faced by the stakeholders with regard to transfer pricing issues. This forum was expected to become one of the annual discussions between DGT and related stakeholders. This national forum was also intended to realize the three main aims (Ditjen Pajak, 2019b), namely:

a. To identify the common problems faced by the tax authority and taxpayers and to find the reasons why the similar problem could be repetitive.

b. To establish a synergy from government body especially each unit under DGT to create a similar system for each procedure, monitoring, audit, litigation and settlement in the tax court.

c. To establish a managerial and strategic step, which is not solely limited to the creation of technical work.

It means that there is a need to reform the tax administration organization, to improve the quality of regulation, to improve the quality of human resources, and to optimize the use of supporting facilities

With all the obstacles and challenges, it could be said that DGT has fully realized that the infrastructure of transfer pricing handling need the support of various aspects, such as (i) the availability of comprehensive rules for both the legal basis and technical guidelines, (ii) the availability of transfer pricing experts and knowledgeable transfer pricing auditors, (iii) the reliable transfer pricing risk management system (iv) taxpayer compliance (v) the synergy with other related parties such as tax consultants and independent auditors that engage with transfer pricing issues.

In the beginning of 2020, Directorate General of Taxation has released Director General of Taxes Regulation No. PER-02/PJ/2020 concerning the Procedure of Tax Examination Abroad with regard to Information Exchange Based on Tax Treaty. This regulation gives the mandate to the tax authority to intensively gather more comprehensive information about the activities between the taxpayers and the other parties under tax treaty. The issuance of this regulation is expected to be able to ease the transfer pricing audit because it enables DGT to collect the information of the related audited taxpayer's transactions through the exchange of information. This measure is to realize the better quality of transfer pricing audit results. 


\section{A Note to Transfer Pricing Audit and Settlement Performed by Indonesian Tax Authority}

The success of transfer pricing provision implementation would evolve through the time depending on (i) the level of economic development in the particular country, (ii) tax administration practices, (iii) human resources capacity, (iv) information technology enhancement, and (v) level of awareness among taxpayers (Abedellatif, 2019). The United Nations really understands that transfer pricing problem is a long-term work to deal with by the developing countries. UN highlights several pertinent recommendations (United Nations, 2009):

a. Developing countries need the transfer pricing experts that possess the comprehensive skills to identify where the allocation of taxing rights seems inappropriate

b. Developing countries need comprehensive transfer pricing regulations including the technical details such as information about documentation required which must be performed by MNEs.

c. The enforcement of the provisions on the disclosure through the country-by-country reporting must be fulfilled by MNEs. The availability of detailed information through the submission of the report will provide the tax authority some information for the targeted audit. This strategy will enable the authority to allocate the resources for audit activities efficiently.

d. The optimization of the effectiveness of tax information exchange. This might also provide some information for tax authority to identify the risky taxpayer.

OECD in 2012 also highlighted the importance of the following management stages to deal with transfer pricing challenges (OECD, 2012):

a. Taxpayers and tax authority have the similar understanding to establish a framework of effective risk management. This framework might consist of several agreed indicators. The existence of these indicators will ease the tax authority to focus on the scope of audit and to make efficient transfer pricing audit.

b. The two-way communication must be made between taxpayers and tax authority during the early stage of transfer pricing audit. The confirmation of the relevant facts related to the transactions and the findings which might be raised during the audit should be dealt in collaborative manner.

c. The report is created based on the transparency process. It will ensure the robustness of each finding and the consistency of the audit process following the prevailing transfer pricing rules.

d. Maintaining the communication on the progress of the case. The delay in the assessment would possibly occur. The cause of the delay should be communicated transparently. If possible, the settlement is conducted through non-litigation or other alternative dispute resolution. A good governance should encourage the reasonable choice whether it needs to bring the case into non-litigation or litigation choice.

e. Transfer pricing audit have urged the tax administration to continuously master the related skills and knowledge. Moreover, it demands highly expertise skills in specific area to establish a reliable transfer pricing report. The mastery of the management system knowledge would be an obligation.

The outcome of an effective transfer pricing audit covers at least two aspects, namely (1) increased future compliance (which indirectly contributes to future tax revenue and protection of the tax base) and (2) increased current tax revenue (in which cases are successfully audited).

\section{Conclusion}

Transfer pricing has been considered as the most common modus of tax avoidance performed by MNEs and has also been considered as a rigorous audit in tax compliance. Transfer pricing is a fact-intensive assessment work and an the same time it does not offer a certain constant formulaic basis like the other exact sciences. The utmost challenges faced by the tax administrator in developing countries on transfer pricing matters are not only the nonexistence of the standardized formula to assess the fairness of transfer pricing transactions, but also lack of capacity, including the available system or mechanism to monitor the MNEs transactions with their related partners. The similar challenges are also faced by Indonesian Tax Authority, Directorate General of Taxes (DGT).

During the fiscal year 2009-2013, the board of judges rejected more than $45 \%$ of transfer pricing audits performed by the tax authority. The reasons of the rejection were lack of convincing readjustments made by the tax auditors in the transfer pricing documentation submitted by the taxpayers, lack of supporting documents prior to the reported transaction, lack of sufficient arguments or proof to the corrections made by the tax auditors. However, the trend was slightly different for the fiscal year 2014-2015, in which the cases brought to the tax court were mostly due to the administrative and technical matters during the tax audits. $40 \%$ of the cases were settled during the fiscal year 2015-2019. Unfortunately, inappropriate assessment process contributed to the larger proportion of the failures in complying with the technical and administrative rulew. On other hand, in terms of nontechnical and administrative issues, DGT tends to win the most of the cases. It means that DGT has become more reliable while doing audit when it has complied with the technical and administrative matters. DGT also fully realizes that the infrastructure of transfer pricing handling needs the support from various aspects, those are (i) the 
availability of the comprehensive rules for both the legal basis and technical guidelines, (ii) the availability of transfer pricing experts and knowledgeable transfer pricing auditors, (iii) reliable transfer pricing risk management system (iv) taxpayer compliance, and (v) the synergy with other related parties.

\section{References}

Bisnis.com. (2015, September 14). Ditjen Pajak Akui Kuwalahan Perangi Transfer Pricing. Bisnis. https://ekonomi.bisnis.com/read/20150914/10/471981/ditjen-pajak-akui-kuwalahan-perangi-transferpricing

Chan, K. H., Lo, A. W. Y., \& Mo, P. L. L. (2015). An empirical analysis of the changes in tax audit focus on international transfer pricing. Journal of International Accounting, Auditing and Taxation, 24, 94-104.

CNBC Indonesia. (2018, February 28). Reformasi Kelembagaan Perpajakan, Jangan Sekadar Ganti Nama. CNBC.

Creswell, J. W. (2014). Research Design: Qualitative, Quantitative, And Method Approached (4th ed.). SAGE Publications Ltd.

Ditjen Pajak. (2019a). Hadapi Pengemplang Asing, DJP Siapkan Strategi Penanganan Transfer Pricing. Direktorat Jenderal Pajak. https://pajak.go.id/id/berita/hadapi-pengemplang-asing-djp-siapkan-strategi-penanganantransfer-pricing

Ditjen Pajak. (2019b). WP Kanwil Jaksus Belajar Susun Dokumen Transfer Pricing. Direktorat Jenderal Pajak. https://www.pajak.go.id/id/berita/wp-kanwil-jaksus-belajar-susun-dokumen-transfer-pricing

Inside Tax. (2013). Di Balik Suap Pajak. DDTC. https://ddtc.co.id/research/publications/insidetax-magazine/insidetax-edisi-15/\#.X8s6dWgzbIW

kontan.co.id. (2019, October 23). Jadi tuan rumah SGTAR, pemerintah harap dapat respons tantangan perpajakan global. Kontan. https://nasional.kontan.co.id/news/jadi-tuan-rumah-sgtar-pemerintah-harap-dapatrespons-tantangan-perpajakan-global

KPMG. (2019). Transfer Pricing adjustments in multinational enterprises: yet another challenge for taxpayers. KPMG. $\quad$ https://home.kpmg/pl/en/home/insights/2019/09/transfer-pricing-adjustments-in-multinationalenterprises-yet-another-challenge-for-taxpayers.html

Lamb, M., Lymer, A., Freedman, J., \& James, S. (Eds.). (2004). Taxation: An Interdisciplinary Approach to Research (1st ed.). Oxford University Press.

McNair, D., Dottey, R., \& Cobham, A. (2010). Transfer Pricing and the Taxing Rights of Developing Countries. Christian Aid. https://www.christianaid.ie/sites/default/files/2017-08/transfer-pricing-november2010_0.pdf

OECD. (2010). OECD Transfer Pricing Guidelines for Multinational Enterprises and Tax Administrations.

OECD. (2012). Dealing Effective with the Challenges of Transfer Pricing. https://doi.org/10.1787/9789264169463-en

OECD. (2017). Transfer Pricing Guidelines for Multinational Enterprises and Tax Administrations. https://www.oecd.org/tax/transfer-pricing/oecd-transfer-pricing-guidelines-for-multinational-enterprisesand-tax-administrations-20769717.htm

Ortax.Org. (2010, November 16). PemerintahBentuk Tim "Transfer Pricing." Kompas. http://www.ortax.org/ortax/?mod=berita\&page=show \&id=10520\&q=kontan\&hlm=80

Prasetyo, D. K. D. (2016). Penentuan metode harga transfer untuk menguji kewajaran transaksi pemberian jasa intra-grup dalam pemeriksaan pajak = The determination of transfer pricing method selection to test the arm's length price of intra-group services transaction in tax audit [Universitas Indonesia]. http://digilib.ui.ac.id/detail?id=20422123\&lokasi=lokal

PWC. (2013). Tax Flash Indonesia, SE-10: Circular on Transfer Pricing Audit. https://www.pwc.com/id/en/taxflash/assets/taxflash_2013-19.pdf

Schön, W., \& Konrad, K. A. (Eds.). (2012). Fundamentals of International Transfer Pricing in Law and Economics. Springer.

Silaban, A. H. (2015). Pertimbangan penentuan data pembanding oleh pemeriksa pajak dalam pemeriksaan terhadap wajib pajak yang memiliki hubungan istimewa = Tax auditors consideration in determining comparable during transfer pricing audit. Universitas Indonesia. 
Simamora, B. E. P. P., \& Hermawan, A. A. (2017). Transfer Pricing Analysis on Intra-Group Services and the Related Transfer Pricing Disputes from Indonesian Tax Perspectives. Proceedings of the 6th International Accounting Conference, 24-28.

Tambunan, M. R. U. D., Rosidiana, H., \& Irianto, E. S. (2020). Minimising Potential Tax Avoidance by Strengthening Transfer Pricing Policy in Indonesia. Austaxpolicy: Tax and Transfer Policy Blog. https://www.austaxpolicy.com/minimising-potential-tax-avoidance-by-strengthening-transfer-pricingpolicy-in-indonesia/

The Jakarta Post. (2014, May 6). Optimism on transfer pricing audit challenges. PT. Niskala Media Tenggara. https://www.thejakartapost.com/news/2014/05/06/optimism-transfer-pricing-audit-challenges.html

United Nations. (2009). Committee of Experts on International Cooperation in Tax Matters : report on the 5th session. https://digitallibrary.un.org/record/677160

United Nations. (2017). Practical Manual on Transfer Pricing for Developing Countries.

Vega, A. (2012). International Governance Through Soft Law: The Case of the OECD Transfer Pricing Guidelines (No. 2012-5). https://papers.ssrn.com/sol3/papers.cfm?abstract_id=2100341 